\title{
A note from the editors: impact of anthropogenic changes to water on human pathogens
}

Eurosurveillance editorial team ${ }^{1}$

1. European Centre for Disease Prevention and Control (ECDC), Stockholm, Sweden

Correspondence: Eurosurveillance editorial team (eurosurveillance@ecdc.europa.eu)

Citation style for this article:
Eurosurveillance editorial team. A note from the editors: impact of anthropogenic changes to water on human pathogens. Euro Surveill. $2016 ; 21(15)$ :pii=30200. DOI: http://dx.doi.org/10.2807/1560-7917.ES.2016.21.15.30200

Article submitted on 14 April 2016 / accepted on 14 April 2016 / published on 14 April 2016

Water safety is vital, and the quality of water important in terms of public health. One of the objectives of the Water Quality and Health Strategy of the World Health Organization (WHO) for the 2013 to 2020 period, is to obtain 'the most rigorous and relevant evidence regarding water quality and health' [1]. In terms of infectious diseases, water can transport pathogens in the environment through different steps of the water cycle $[2,3]$. In the water, some physical or chemical parameters, e.g. temperature, $\mathrm{pH}$, salinity, organic matter, may affect the survival of the pathogens [4]. Substances intended to control pathogens or insects (antimicrobials, antivirals and pesticides) can occur in water subsequent to their use $[5,6]$ or manufacturing process $[7,8]$. This may paradoxically induce pathogen or vector resistance to these substances [9-12]. Moreover, water can also bear a number of pathogens with resistance acquired through other pathways [13]. Exposure of people to waterborne pathogens may occur by drinking or swallowing water, inhaling aerosolised droplets and contact with water through bathing and recreation $[14,15]$. Some pathogens may also be disseminated by water further in the environment (e.g. in the soil and air) potentially allowing human exposure. Consuming foods, grown on/in or irrigated with pathogen-contaminated water may also lead to infection $[16,17]$.

As a number of changes to water, e.g. canalisation, temperature, nutrient enrichment, addition of pestcontrol or antimicrobial/viral substances, and pathogen contamination, result from human activities, it is relevant to understand their impact on infectious disease epidemiology. To provide some examples relevant for European public health, and to present issues related to the detection and identification of cases of waterborne outbreaks and the proof of anthropogenic change to water as the cause, we issued a call for papers [18]. Subsequent to this, we now publish five articles, through which a number of issues arise and which can be summarised as follows.
The challenges of outbreaks potentially caused by microbial contamination of water are first illustrated in a report from Italy, where an outbreak of monophasic Salmonella Typhimurium 1,4 [5],12:i:- with sole resistance to nalidixic acid is described [19]. Attempts to determine the source of this outbreak led to extensive environmental investigations. While its cause could not be ascertained, a number of surface water samples in the outbreak area, including of water used for growing fruit and vegetables, were positive for the outbreak strain. Moreover some water samples from local sewage treatment plants also tested positive, thus leading to the hypothesis that wastewater may have contaminated irrigation water [19]. The epidemiological investigation was complicated and the origin of the outbreak strain and how this strain acquired its resistance to nalidixic acid remain unresolved. The study reinforces the value of detecting waterborne outbreaks early.

Generally, water may become contaminated from a non-point source, such as the runoff of water from manure in agricultural fields, or from a point discharge, such as a hospital wastewater outlet or a sewage treatment plant. The issue of clinical wastewater harbouring microorganisms resistant to antimicrobials, and its subsequent effect on sewage and freshwater is important for public health, particularly if resistant bacteria introduced in the water can not only survive but also grow in wastewater. Acinetobacter baumanni for example, is considered a nosocomial pathogen, but its ecology is as of yet not fully understood and the observation of community outbreaks has made environmental niches suspect. A study from Croatia finds multiresistant $A$. baumannii strains in both influent and effluent water to a sewage treatment plant in Zagreb, indicating that such strains can evade the treatment process. The study shows moreover that isolated strains can survive and grow in effluent sewage water up to 50 days, posing a potential risk for further dissemination in the recipient river to the plant [20]. 
As a risk exists for surface water to become contaminated by wastewater pathogens, there is relevance in fully assessing its safety for further human use. A study from Serbia conducted during the bathing season reveals adenovirus and rotavirus genetic materials in recreational waters of the Danube, along popular public beaches in addition to faecal contamination. As the presence of viruses could not necessarily be predicted by the amount of bacteria measured in the water via routine quality control, the authors conclude that viral indicators may be helpful for further assessing the risks posed by water, in particular in areas where the sewer network is insufficient or inadequate [21].

Which panels of viruses could serve as relevant indicators of water quality in certain circumstances would need further investigations, as this may depend in part on their infectivity doses and persistence in environmental water. Also this might require to know what potential viruses contaminate the water to begin with, possibly first requiring agnostic screening techniques. In this regard, the development and implementation of assays that can be used for the surveillance of the whole population of viruses in water samples can be of interest. In this special issue, a methodology combining tangential flow filtration of sewage combined with deep sequencing, without the need for cell culture, is presented as an agnostic approach to survey viruses in sewage. The use of this methodology is proposed for the surveillance of poliovirus, but broader applications, including creating new viral sequence databases for retrospective analysis of presently unknown human viruses that may be discovered in the future are suggested [22].

Should it be a priori known what viruses likely contaminate water in an area, defining more specific tools to confirm their presence may be considered. Moreover in terms of further risk assessment, and as also discussed in the Serbian study in this issue [21], assays to determine the presence of infectious virus might also be of value.

As illustrated by some of the above studies [19,21], adequate management of wastewater is crucial. Indeed, water contaminated by wastewater can subsequently cumulate in larger water bodies such as lakes or the ocean. There, its impact may be less clear, as not only pathogens, but supportive nutrients may be carried by the wastewater. In combination with meteorological factors such as temperature, this may lead to the sporadic or intermittent occurrence of 'exotic' or 'unusual' pathogens in some areas [4]. An article from the Netherlands describes three cases of Vibrio cholera non-01 serogroup (VCNO) bacteraemia reported in the country. Cases had been prior exposed to fish and/or had contact with surface water. The Dutch study includes a review of the literature to identify sources and risk factors for bacteraemia [23].
In conclusion, this special issue provides some insights into the importance of surveillance of pathogens in the water [19-23] and outbreaks or cases caused by waterborne pathogens $[19,21,23]$. Wider studies could help further refine criteria for assessing water treatment processes. Through pollution of ground water with antimicrobials and multi-resistant bacteria, waterborne outbreaks of multi-resistant bacteria are likely to become more frequent in the future. The special issue illustrates that addressing the problems due to anthropogenic changes to water on the epidemiology of human pathogens will require a multi-disciplinary approach.

\section{References}

1. World Health Organization (WHO). Water Quality and Health Strategy 2013-2020. Geneva: WHO; 2013. Available from: http://www.who.int/water_sanitation_health/ publications/2013/water_quality_strategy/en/

2. World Health Organization (WHO). Guidelines for drinking water quality.3rd edition. Geneva: WHO; 2008. Chapter 11, Microbial fact sheets. Available from: http://www.who.int/ water sanitation health/dwq/GDW11rev1and2.pdf

3. Huckele S, Track T. Risk management of emerging compounds and pathogens in the water cycle (RiSKWa).Environmental Sciences Europe.2013;25:1. DOI: 10.1186\%2F2190-4715-25-1

4. Hunter PR. Climate change and waterborne and vector-borne disease.J Appl Microbiol. 2003;94(s1) Suppl;37S-46S. DOI: 10.1046/j.1365-2672.94.S1.5.x PMID: 12675935

5. Sura S, Degenhardt D, Cessna AJ, Larney FJ, Olson AF, McAllister TA. Transport of three veterinary antimicrobials from feedlot pens via simulated rainfall runoff.Sci Total Environ. 2015;521-522:191-9. DOI: 10.1016/j.scitotenv.2015.03.080 PMID: 25839178

6. Chee-Sanford JC, Mackie RI, Koike S, Krapac IG, Lin YF, Yannarell AC, et al. Fate and transport of antibiotic residues and antibiotic resistance genes following land application of manure waste. J Environ Qual. 2009;38(3):1086-108. DOI: 10.2134/jeq2008.0128 PMID: 19398507

7. Marathe NP, Regina VR, Walujkar SA, Charan SS, Moore ER, Larsson DG, et al. A treatment plant receiving waste water from multiple bulk drug manufacturers is a reservoir for highly multi-drug resistant integron-bearing bacteria. PLoS One. 2013;8(10):e77310. DOI: 10.1371/journal.pone.0077310 PMID: 24204801

8. Larsson DG, de Pedro C, Paxeus N. Effluent from drug manufactures contains extremely high levels of pharmaceuticals.J Hazard Mater. 2007;148(3):751-5. Available from: DOI: 10.1016/j.jhazmat.2007.07.008 PMID: 17706342

9. Kümmerer K. Antibiotics in the aquatic environment--a review-part I. Chemosphere. 2009;75(4):417-34. DOI: http://dx.doi. org/10.1016/j.chemosphere.2008.11.086

10. Söderström H, Järhult JD, Olsen B, Lindberg RH, Tanaka H, Fick J. Detection of the antiviral drug oseltamivir in aquatic environments.PLoS One. 2009;4(6):e6064. DOI: 10.1371/ journal.pone.0006064

11. Berglund B. Environmental dissemination of antibiotic resistance genes and correlation to anthropogenic contamination with antibiotics. Infect Ecol Epidemiol. 2015;5:28564.

12. Brogdon WG, McAllister JC. Insecticide resistance and vector control.Emerg Infect Dis. 1998;4(4):605-13. DOI: 10.3201/ eido404.980410 PMID: 9866736

13. Walsh TR, Weeks J, Livermore DM, Toleman MA. Dissemination of NDM-1 positive bacteria in the New Delhi environment and its implications for human health: an environmental point prevalence study.Lancet Infect Dis. 2011;11(5):355-62. DOI: 10.1016/S1473-3099(11)70059-7 PMID: 21478057

14. Pandey PK, Kass PH, Soupir ML, Biswas S, Singh VP. Contamination of water resources by pathogenic bacteria.AMB Express. 2014;4(1):51. DOI: 10.1186/S13568-014-0051-x PMID: 25006540

15. World Health Organization (WHO). Bartram J, Chartier Y, Lee JV, Pond K, Surman-Lee S, Editors. Legionella and the prevention of legionellosis. Geneva: World Health Organization (WHO); 2007. Available from: http://www.who.int/water sanitation health/emerging/legionella.pdf 
16. Centers for Disease Control and Prevention (CDC). Water Contamination. Atlanta: CDC; [Accessed 12 Apr 2016]. Available from: http://www.cdc.gov/healthywater/other/agricultural/ contamination.html

17. Food and Agriculture Organization of the United Nations (FAO). Quality control of wastewater for irrigated crop production. Rome: FAO; 1997. Chapter 2 - Health risks associated with wastewater use. Available from: http://www.fao.org/docrep/ w5367e/w5367e04.htm

18. Eurosurveillance editorial team., Call for papers for a special issue on impact of anthropogenic changes to water on human pathogens. Euro Surveill. 2015;20(2):21010.

19. Cito F, Baldinelli F, Calistri P, Di Giannatale E, Scavia G, Orsini $M$, et al. Outbreak of unusual Salmonella enterica serovar Typhimurium monophasic variant 1,4 [5],12:i:-, Italy, June 2013 to September 2014. Euro Surveill. 2016;21(15):30194. DOI: 10.2807/1560-7917.ES.2016.21.15.30194

20. Hrenovic J, Goic-Barisic I, Kazazic S, Kovacic A, Ganjto M, Tonkic M. Carbapenem-resistant isolates of Acinetobacter baumannii in a municipal wastewater treatment plant, Croatia, 2014. Euro Surveill. 2016;21(15):30195. DOI: 10.2807/1560-7917. ES.2016.21.15.30195

21. Jovanović Galović A, Bijelović S, Milošević V, Hrnjaković Cvjetkovic I, Popović M, Kovačević G, et al. Testing for viral material in water of public bathing areas of the Danube during summer, Vojvodina, Serbia, 2014. Euro Surveill. 2016;21(15):30196. DOI: 10.2807/1560-7917. ES.2016.21.15.30196

22. Furtak V, Roivainen M, Mirochnichenko O, Zagorodnyaya T, Laassri M, Zaidic SZ, et al. Environmental surveillance of viruses by tangential flow filtration and metagenomic reconstruction. Euro Surveill. 2016;21(15):30193. DOI: 10.2807/1560-7917.ES.2016.21.15.30193

23. Engel MF, Muijsken MA, Mooi-Kokenberg E, Kuijper EJ, van Westerloo DJ. Vibrio cholerae non- $0_{1}$ bacteraemia: description of three cases in the Netherlands and a literature review. Euro Surveill. 2016;21(15):30197. DOI: 10.2807/1560-7917. ES.2016.21.15.30197

\section{License and copyright}

This is an open-access article distributed under the terms of the Creative Commons Attribution (CC BY 4.0) Licence. You may share and adapt the material, but must give appropriate credit to the source, provide a link to the licence, and indicate if changes were made.

This article is copyright of the European Centre for Disease Prevention and Control, 2016. 